\title{
Pragmatic Losses of Qur'an Translation: A Linguistic Approach
}

\author{
Amir El-Said Ebrahim Al-Azab ${ }^{1} \&$ Othman Abdulaziz Al-Misned ${ }^{2}$ \\ ${ }^{1}$ University of Dammam, KSA \\ ${ }^{2}$ Department of Languages and Translation, King Fahd Security College, Riyadh, KSA \\ Correspondence: Amir El-Said Ebrahim Al-Azab, University of Dammam, KSA. E-mail: azab789@yahoo.com
}

Received: June 27, 2012

Accepted: July 20, $2012 \quad$ Online Published: August 20, 2012

doi:10.5539/ells.v2n3p42

URL: http://dx.doi.org/10.5539/ells.v2n3p42

\begin{abstract}
This paper seeks to highlight the phenomenon of pragmatic losses in the translation of the meanings of the Qur'an from a linguistic point of view. It focuses on pragmatics. Hence, it tackles loss of genre, texture, culture-specific terms, word order, syntactic conflict, ellipsis, gender and tense. This is a link between pragmatics and translation.
\end{abstract}

Keywords: pragmatic loss, genre, texture, culture-specific term, linguistic prevalence, word order, ellipsis, gender, tense

\section{Introduction}

The issue of pragmatic loss has been hotly debated within the scope of pragmatics and translation. It is one of the most intractable issues of translation. Armstrong (2005) states that "energy loss is inevitable; similarly, the translator's aim is to reduce translation loss" (p.46).

In fact, pragmatic losses extinguish the pleasure of the text. They cloud our partial understanding of meaning. The dilemma is that there is an area of conflict between the source language and target language. There is no pragmatic matching. Translation cannot create an identical TL copy of the SL text. Perfect translation falls beyond human capacity.

A maximal approximation can be achieved via frequent strategies. A strategy is "compensation": accepting the loss of one element in the TT, and compensating by adding an element elsewhere (ibid: 46). Translators have been at pain to achieve the greatest responsibility laid upon them. Dickins, Hervey and Higgins (2002) point out that the challenge to the translators is "Which features can most legitimately be sacrificed" (p.25).

The loss of nuances is the tax of translation. Facing such a plethora of linguistic problems necessitates scrutiny, precision and meticulousness on the part of translators. This vibrant area deals a blow at the heart of the translational process.

The method of the research is comparative and analytic or critical. The researcher criticizes the translation in relation to pragmatics and the functionality of linguistic differences. The researcher also analyzes the translations drawing a comparison between them to show the accurate points and the less accurate points, accounting for them scientifically. The study is based on a clear-cut methodology. It is the working of pragmatics and the differentiation between synonyms. Thus, correcting mistakes is a vital factor in the translational process.

\section{Different Manifestations of Pragmatic Losses}

\subsection{Loss of Genre in Translation}

Genre is a type of text that has certain formal characteristics which mark it out as playing specific cultural, functional or literary role (Pellatt, 2010). The unique genre of the Qur'an challenges mankind. The Qur'an is inimitable. It is the immortal linguistic miracle. It cannot be possible for any translator to imitate the genre of the Qur'an. All these translations are but attempts to approximate the meaning of the Qur'an. The formidable task of approximation has burdened the shoulders' of translators.

The problem of genre in translation is particularly acute when a text is remote from target language readers (Bassnett, 2006). The independent genre of the Qur'an captivates both readers and listeners. Abdul-Raof, (2001) states that "the Qur'an itself will be lost when translated; its unique linguistic architecture, rhetorical beauty, music, and prototypical texture will be wasted" (p.40). Moreover, context- sensitivity of the Qur'anic genre falls 
beyond the domain of translation. Lawrence (2006) states that "Qur'anic verses are expressive of an inexhaustible truth. They signify meaning layered with meaning, light upon light, miracle after miracle" (p.8).

\subsection{Losses of Texture in Translation}

Walter Nash (1980) states that texture refers to "the coloring and fleshing of the text with imagery, metaphor, dominant motifs, figures of speech, powerfully evocative language, and all the resources of address and persuasion" (p.46). As a matter of fact, texture is usually considered to be created by the two phenomena, cohesion and coherence, which interact closely (Malmkjaer, 2005).

Halliday and Hasan (1976) point out that "texture is meant the qualities that cause a stretch of language to be read as a text rather than as an unordered and unorganized jumble of linguistic items" (p.2). In fact, Qur'anic texture cannot be translated. There must be a kind of loss. Adbul-Raof (2001) stresses the fact that "the target language cannot accommodate the linguistic and/or the rhetorical norms of the Qur'anic discourse" (p.109). Linguistic norms differ from one language to another. This poses a big problem to translators. The fabric of the text falls beyond human capacity.

On the other hand, Robbins (1996) classifies texture into inner texture, intertexture, ideological texture and sacred texture. Inner texture concerns "the features in the language of the text itself" (Robbins, 1996, p.7). He sheds light on the patterns of repetition, progression, narration and argumentation. He defines the intertexture as "entering the interactive world of a text" (ibid: 40). He highlights the cultural, social and historical perspectives. As for the "ideological" texture, he moves the focus beyond the text and its world to readers and their diverse perspectives. This reflects the beliefs and views shared by groups. Finally, Robbins regards the "sacred" texture as "the ways the text speaks about God, or talks about realms of religious life" (ibid: 120). He sheds light on the sensitive nature of the relation between human life and divine matters.

A versed translator should investigate the various arenas of texture in order to see the wider picture. Nash (1980) points out that the formidable task of a translator is "to combine textural appeal with an appropriate scheme of textual cohesion, in such a way that one supports the other" (p.62). At the end, there must be a kind of loss in translation; complete equivalence and perfect copying are kinds of mirage. Bell (1991) points out that "the ideal of total equivalence is a chimera and languages are different from each other; they are different in form having distinct codes and rules regulating the construction of grammatical stretches of language and these forms have different meanings" (p.6). This reflects the fact that this integrated package of texture cannot be imitated due to its uniqueness. It is outside the orbit of translation.

\subsection{Loss of Textual Meaning in Translation}

Textual meaning refers to the way the text is organized as a piece of writing (Eggins, 1994). Abdul-Raof (2001) further states that "the textual meaning is the way in which a text is structured by varying types of linguistic resource to link the ideas being expressed and make them hang together" (p.14).

It is a clear-cut fact that the translated text suffers a lot. Every text has its own stamp. Smalley (1991) points out that, "to have textual equivalence simply seems beyond the reach of many translators" (p.129). As a wife does not accept a co-wife, a language also does not accept a co-language. Perfection in translation falls beyond human capacity. The truth of approximation is the prevalent tone in the translational symphony. That area of conflict bothers translators. Baker (1992) points out that "unlike the Arabic grammatical system, the English system makes very few distinctions in terms of number, gender, and verb agreement" (p.190).

\subsection{Loss of the Referential Versatility of Qur'anic Words}

The referential versatility of a Qur'anic word refers to the fact that a word may embrace a large number of sense-components. The meaning of a word, in this case, is usually extended to include various aspects and multi-dimensions. It is not easy, for the translator, to resolve this problem of multiplicity. This versatility poses a big problem to translators.

Consider the following example in the sura of The Pen:

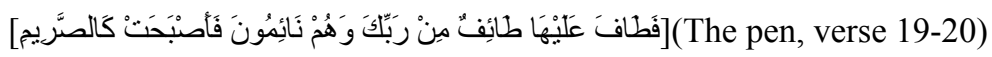

So the (garden) became black by the morning, like a pitch dark night. (Al-Hilali and Khan, verse 20)

And in the morning it was as if plucked. (Pickthall, verse 20)

And in the morning it was as if it were a garden plucked. (Arberry, verse 20)

Ghoneim (2010) states that commentators of the Qur'an differ in the interpretation of the word "الصريم" as follows: 
a) pitch dark night (Al-Fara')

b) black ashes (Ibn Abbass)

c) the morning when it is stripped from night (Al-Akhfash)

d) cut-down crop (Al-Thawry and Ibn Quttaiba)

The translators of the noble verse have adopted an exegetical point of view. They differ in their interpretation of "الصريم". This is because of the multifaceted nature of the lexeme. Fatani (2006) points out that "the basic problem with the majority of translations is that translators tend to simplify the enormous problems involved in defining the exact referential and denotational meanings of complex words by restricting their range of selection to a narrow domain" (p.661). This umbrella term shackles translators. A one-to-one match in translation is a kind of illusion.

\section{5) Loss of Culture-Specific Terms}

The source-language word may express a concept which is totally unknown in the target culture. The concept in question may be abstract or concrete; it may relate to a religious belief, a social custom, or even a type of food. Such concepts are often referred to as "culture-specific" (Baker, 1992, p.21). This is one of the cultural bumps that pose problems for translators. There is a surprising gap between the SL and the TL. Ideology is the problem. There are different tenets and creeds that sow the seeds of difference.

Consider the following example in the sura of the Cow:

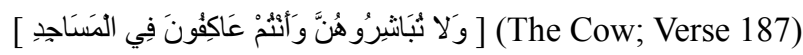

a) And do not have sexual relations with them while you are in I'tikaf (i.e. confining oneself in a mosque for prayers and invocations leaving the worldly activities). (Al-Hilali and Khan, verse 187)

b) And touch them not, but be at your devotions in the mosques. (Pickthall, verse 187)

c) And do not lie with them while you cleave to the mosques. (Arberry, verse 187)

Catford (1965) states that "cultural untranslatability" arises "when a situational feature, functionally relevant for the SL text, is completely absent from the culture of which the TL is a part" (p.99).

Al-Hilali and Khan have resorted to phonological transliteration due to the gap between the SL and the TL. They have paraphrased the term because it is a semantic void. This concept is outside the orbit of the non-Islamic discourse. None of the other suggested translations will do. It is culture-bound. Enani (2000a) points out that "no matter how clever the translator is, there will remain a discrepancy between the Arabic version and the original English" (p.53).

For the sake of approximating the meaning, the researcher suggests to translate "the culture-specific" term in the noble verse as "consecrating". There is a kind of partial synonymy, but the overall pragmatic overtones are lost.

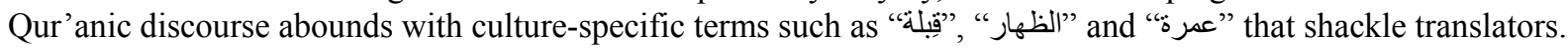
This problem is one of the most challenging tasks to be performed by translators.

6) Loss of Prevalence or "Taghlib"

Wright (1967) points out that "when two objects are constantly associated, in virtue either of natural connection or opposition, a dual may be formed from one of them, which shall designate both, or the preference given to the one over the other is termed - التغليب i.e. making it prevail over the other" (p.187). Here are two examples:

= the two white ones = milk and water (natural link)

المشرقان= East and west (opposition)

Prevalence is "language specific". It is a linguistic phenomenon used for the rhetorical and pragmatic purposes. It intensifies the meaning and reflects ease of use; it is used for what is common and popular in language. Every language has its own strategies. This pragmatic device bothers translators. Consider the following instance in the sura of the Cave:

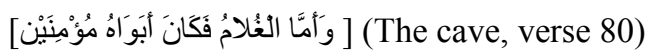

And as for the boy, his parents were believers. (Al-Hilali \& Khan, verse 80)

And as for the lad, his parents were believers. (Pickthall, verse 80)

As for the lad, his parents were believers. (Arberry, verse 80 )

All these translations suffer a kind of loss. There is a loss of prevalence or "Taghlib". Literally, the word "بواهو 
means his two fathers. There is a natural connection between the father and the mother. The father prevails over the mother for socio-cultural reasons. In Arabic, the masculine prevails over the feminine for pragmatic reasons. Linguistic norms differ in English and Arabic.

A translator must be aware of this pragmatic information. Hartmann and James (1998) point out that "pragmatic information refers to information on the socio-cultural rules of speaking. Exponents include paralinguistic features such as the choice of vocabulary which can reinforce the speaker's intended meaning" (p.111). Translators should investigate this nuanced area in pragmatics and translation.

\section{7) Loss of Word Order}

Word order is the special arrangement of words. Its typology refers to the study of the order of the syntactic constituents of a language, and how different languages can employ different orders. English and Arabic differ in the system of word order. This difference complicates the process of translation. Abdul-Raof (2006) states that "different word orders express variegated propositional attitudes and carry an illocutionary force, i.e. they lead to different inferable interpretations on the part of the addressee" (p.101).

Devine and Stephens (2006) further state that "the study of word order is of real practical value to anyone who uses texts as a source of information" (p.5). The pragmatic and aesthetic effects of word order can be lost in translation. Consider the following example in the sura of the Cow:

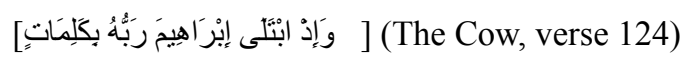

And (remember) when the Lord of Abraham tried him with certain commands. (Al-Hilali \& Khan, verse 124)

And (remember) when his Lord tried Abraham with (His) commands. (Pickthall, verse 124)

And when his Lord tested Abraham with certain words. (Arberry, verse 124)

There is a loss in the translation of the verse. There is an area of conflict between Arabic and English. Word order differs. Lambrecht (1994) states that, "focus is what makes an utterance into an assertion" (p.207). The inversion in the verse is lost: it adds a new layer of meaning to the spectrum of the verse. Dik (2007) states that "this excess of meaning does not stop interpretation in its tracks, and linguists live and breathe in the reconstruction of communicative intentions of speakers and communicative effects on listeners" (p.251). Deviation from the norm due to the contextual and pragmatic factors poses a great obstacle to translators. The discursive functions of word order bother translators. Foregrounding comes around the center of the hub of pragmatics and translation.

Baker (1992) sums up the thorny problem, and states that "the syntactic structure of a language imposes restrictions on the way messages may be organized in that language. The order in which functional elements such as subject, predicator, and object may occur is more fixed in some languages than in others" (p.110). This reflects how the canonical word order is a peculiarity of each language.

\section{8) Loss of Syntactic Conflict}

The case of syntactic conflict has been underestimated in pragmatics and translation. It is possible to speak volumes about this linguistic nut. Syntactic conflict occurs when the two main verbs in the sentence share the same object. Consider the following example in the sura of The Cave:

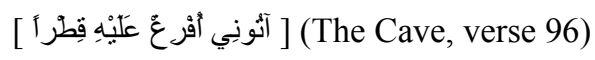

Bring me molten copper to pour over them. (Al-Hilali and Khan, verse 96)

Bring me molten copper to pour thereon. (Pickthall, verse 96)

Bring me, that I may pour molten brass on it. (Arberry, verse 96)

These translations suffer the pragmatic loss of the syntactic conflict. The word " قطر أ " object of the verb " أفرغ " or a direct object (DO) of the verb "ئتوني". This kind of conflict enriches the interpretations of the verse. It has been lost in translation because English does not permit such a construction but Arabic does. The serial verb construction (SVC) integrates the meaning.

From a philological point of view, the researcher suggests that there is a kind of conflict at the syntactic level as well as the semantico-pragmatic level. There is a conflict or an interaction between the fiery iron and the molten copper. Moreover, there is a conflict between Gog and Magog people and the climbing and digging of the mountain-cliff. This semantic meaning is implied in the syntactic conflict in the sense that there is a conflict at the semantico-pragmatic level as well as the syntactic level. Thus, the linguistic miracle of the Qur'anic discourse looms over the text. 
From a philosophical point of view, this construction reflects the fact that great characters, like Dhul-Qarnain, utter great sentences. The syntactic structure highlights the highly elevated language of the good king, Dhul-Qarnain. These hidden nuances do enrich the process of translation.

\section{9) Loss of the Exaggerated Form}

The exaggerated form is a morpho-syntactic peculiarity of the Arabic language. It expresses a greater degree of exaggeration. What raises problems in translation is that this form has no match in English. The form has a function other than its own semantic meaning. A translator may resort to make up for this kind of loss via the use of intensifiers or any suitable semantic component.

Consider the following example in the sura of Joseph:

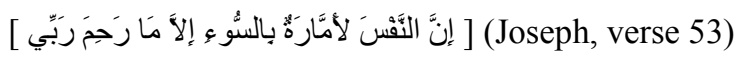

Verily, the (human) self is inclined to evil, except when my lord bestows His mercy (upon whom He wills). (Al-Hilali \& Khan, verse 53)

Lo! The (human) soul enjoineth unto evil, save that whereon my lord hath mercy. (Pickthall, verse 53)

Surely the soul of man incites to evil-except in as much as my Lord had mercy. (Arberry, verse 53)

These translations are not apt. the exaggerated form of " أمَّارَ" " has been lost in translation. Both Pickthall and Arberry have not been faithful to the SL. They have shifted the exaggerated form into verbs. This distorts the message. While Al-Hilali and Khan have not observed the emphatic factor and they have not compensated for the loss of the exaggerated form. The researcher suggests translating the form as "is constantly commanding".

\section{0) Loss of Absolute Object or Cognate}

The absolute object is a noun derived from the same verb. It signifies its type and its number. It has a pragmatic force that reinforces the meaning of the verb. William Wright (1967) points out that it is used for "strengthening, or for magnifying" (p.54). Moreover, it denies metaphoricity of usage. The big problem is that this syntactic peculiarity of Arabic has no counterpart of English. A translator may resort to a remedial strategy to bridge this gap.

Consider the following example in the sura of the Cave:

[ فَجَمَنْنَاهُمْ جَمْعَ (The Cave: verse 99)

And we shall collect them (the creatures) all together. (Al-Hilali and Khan, verse 99)

Then we shall gather them together in one gathering. (Pickthall, verse 99)

And we shall gather them together. (Arberry, verse 99)

These translations suffer the loss of the absolute object. It is untranslatable. Ghali (2005) states that, "Arabic has a rich morphological and syntactic structure" (ix). The rules of Arabic and English are greatly different. "Together" used by the translators is an adverb, not a noun. Contrastive syntax is a wide gap between Arabic and English. This thorny problem challenges translators. What an exhaustive art translation is!

\section{1) Loss of Ellipsis}

Ellipsis is the omission from a sentence or an utterance of material which logically necessary, but which is recoverable from the context (Trask, 1999, p.58). Its pragmatic function is to achieve cohesion and coherence. Clark (1991) points out that "ellipsis is possible only so long as what is missing is reconstructable by the listener" (p.227). The dilemma is that the Arabic language permits such a construction, but English does not in such a case. Consider the following example in the sura of Thunder:

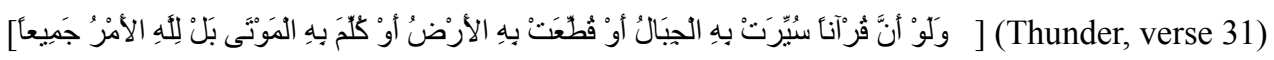

And if there had been a Qur'an with which mountains could be moved, or the earth could be cloven asunder, or the dead could be made to speak (it would not have been other than this Qur'an). (Al-Hilali \& Khan, verse 31)

Had it been possible for a Quran to cause the mountains to move or the earth to be torn asunder, or the dead to speak, (this Qur'an would have done so). (Pickthall, verse 31)

If only a Koran whereby the mountains were set in motion, or the earth were cleft, or the dead were spoken to-nay, but God's is the affair altogether. (Arberry, verse 31)

It is clear that the result depending upon the condition is ellipted. Arberry's translation is unintelligible and inaccessible to the English reader though it is faithful to the original. Both Al-Hilali and Pickthall have resorted to make up for the ellipted part to meet the norm and to disambiguate the meaning. But there is a loss of the 
pragmatic function of ellipsis.

On every level of the translation process, it can be shown that, if linguistic considerations enter into conflict with considerations of an ideological and /or poetological nature, the latter tend to win out (Lefevere, 1992).

Consider another example in the sura of Women:

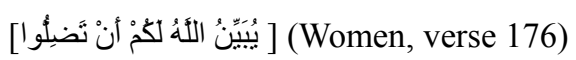

(Thus) does Allah make clear to you (His Law) lest you go astray. (Al-Hilali and Khan, verse 176)

Allah expoundeth unto you, so that ye err not. (Pickthall, verse 176)

God makes velar to you, lest you go astray. (Arberry, verse 176)

In Arabic rhetoric, it is obvious that there is an omission of the negative particle "ل" (Ghoneim, 2010, p.246). Though there is a loss of ellipsis in Pickthall's translation, it has conveyed the intended meaning. Al-Hilali and Arberry have ignored the concept of ellipsis in the noble verse. To set parameters for construing is a must in order not to distort the message of the Noble Qur'an. This reflects that ellipsis is one of the problematics of translation.

\section{2) Loss of Gender}

Trask (1999) defines gender as "the classification of nouns in two or more classes with different grammatical properties" (p.66). A translator encounters some problems in the translation of gender from Arabic into English due to the differentiation in the morpho-syntactic structures. Simon (1996) points out that "grammatical gender means that nouns are placed in classes not according to their meaning, but according to their form...English has 'natural' gender rather than grammatical gender" (p.16). The English lexicon does not specify whether a noun is masculine or feminine, except natural gender (man/woman).

Consider the translation of gender in the following example in the sura of the Pilgrimage:

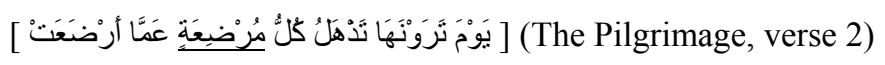

The day you shall see it, every nursing mother will forget her nursling. (Al-Hilali and Khan, verse 2)

On the day when ye behold it, every nursing mother will forget her nursling. (Pickthall, verse 2)

On the day when you behold it, every suckling woman shall neglect the child she has suckled. (Arberry, verse 2)

In Arabic, the word " مرضع" is a natural feminine. There is no need for the use of $t a$ ' of feminization. Generally speaking, it cannot be used for a masculine noun, but this lexeme sometimes needs to have $t a$ ' of feminization. This serves a pragmatic function as in the case of the noble verse. Al-Zamakhshari (2000) pointed out that "there is a slight difference between 'مرضع' and 'مرضعة', the word 'مرضعة' means that she is in the state of suckling now, but the word 'مرضع' does not mean that she is suckling or feeding her baby now. It is her habit." (p.211)

Therefore, these translations are not appropriate. They suffer the loss of pragmatic gender. A translator may compensate that loss via the use of "now" as a time marker to convey the intended meaning and to shed light on the pragmatic function. Moreover, he should delve into the philological nuances of such pragmatic phenomena. Simon (1996) states that, "the translator must earn the right to intimacy with the text" (p.136). This is for the sake of achieving precision of translation.

\section{3) Loss of Grammatical Category}

The grammatical system of Arabic differs from the grammatical system of English. Every language has its own mechanisms. The domain of "difference" between the two languages constitutes a problem in the face of translators. A translator may be obliged to shift the grammatical category of a word. Consider the following instance in the sura of The Bee:

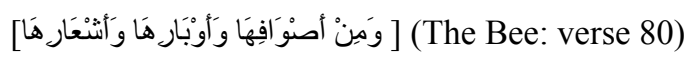

And of their wool, fur, and hair. (Al-Hilali and Khan, verse 80)

And of their wool and their fur and their hair. (Pickthall, verse 80)

And of their wool, and of their fur and of their hair. (Arberry, verse 80)

The translators have been obliged to shift the SL plural category to the TL singular to meet the norms. Catford (1965) states that "intra-system shifts occur when SL and TL possess systems which approximately correspond formally as to their constitution, but when translation involves selection of a non-corresponding term in the TL system, for instance, when the SL singular becomes a TL plural and vice versa" (p.80). 
Category shift in the translational process is sometimes an unavoidable phenomenon; there must be a kind of loss due to the differentiation in the grammatical system. Total equivalence in translation is a kind of myth.

Consider another example in the sura of the Winnowers:

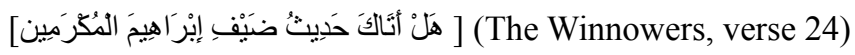

Has the story reached you, of the honored guests of Abraham? (Al-Hilali and Khan, verse 24)

Hath the story of Abrham's honored guests reached thee? (Pickthall, verse 24)

Hast thou received the story of the honored guests of Abraham? (Arberry, verse 24)

Bashir (1998) points out that "The word " ضيف" as a singular may be used to refer to the plural case" (p.84). It may refer to the singular as well as the plural. The translators have been obliged to shift it into plural in translation to cope with " المكرمين" as a plural. Translation is possible, but there is a kind of loss in the grammatical category.

14) Loss of Tense

David Crystal (2008) States that tense is "a category used in the grammatical description of verbs, referring primarily to the way the grammar marks the time" (p.479). Translating the tense from Arabic into English poses a big problem in the face of translators in some cases. The past tense in Arabic can signify a future reference.

The relationship between tense and time has been the subject of much study, and it is now plain that there is no easily satiable relationship between the two (ibid: 479). Consider the following example in the sura of The Cave:

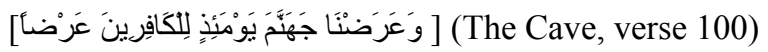

And on that day we shall present Hell to the disbeliever's plain to view. (Al-Hilali \& Khan, verse 100)

On that day we shall present Hell to the disbelievers, plain to view. (Pickthall, verse 100)

And upon that day we shall present Gehenna to the unbelievers. (Arberry, verse 100)

These translations suffer the loss of the past tense. The Qur'an describes the events of Judgment Day in the past tense, although Judgment Day will come in the future. Beside other reasons for this usage, the simple past tense in Arabic is also used to give the meaning that a future event will doubtlessly take place (Ünal, 2006, p.24).

There is a kind of assertion and emphasis that the action will happen in the future. The pragmatic overtones and undertones have been lost in translation. The use of the past tense in Arabic signifies this fact, but the use of the past tense in English is a different story. Here is the dilemma. There is a kind of clash or conflict between the mother tongue and the target language or rather the SL and the TL. This defies translators.

\section{Conclusion}

To conclude, the research seeks to highlight the eloquence and rhetoric of the Qur'an in using certain words, structures, formulae, and articles. It mirrors the miraculousness of the Ever-Glorious Qur'an .The word of Allah cannot be imitated. Every word and sound is intended. Therefore, pragmatic loss is a must in translation. This loss has been represented in genre, texture, culture-specifics, linguistic prevalence, word order, ellipsis, gender and tense.

Finally, pragmatic losses play a vital role in the art and science of translation. It is a thorny problem that poses various hurdles in the face of translators of the Ever-Glorious Qur'an. It is insurmountable. What a pity! The solution of this problem is the linguistic compensation for the sake of approximation of meaning via pragmatics.

\section{References}

Abdul-Raof, H. (2001). The Qur'an Translation: Discourse, Texture and Exegesis. London: Routledge.

Abdul-Raof, H. (2006). Arabic Rhetoric: A pragmatic Analysis. London: Routledge.

Al-Zamakhshari, Abu Al-Qasim. (2000). Al-Kashaf(Vol-4). Cairo: Maktabat Misr.

Arberry, Arthur J. (1982). The Koran Interpreted. Oxford: Oxford University Press.

Armstrong, N. (2005). Translation, Linguistics, Culture. Clevedon: Multilingual Matters Ltd.

Baker, M. (1992). In Other Words: A Course Book on Translation. London and New York: Routledge. http://dx.doi.org/10.4324/9780203327579

Bashir, Aziza Y. (1998). Al-Nahw fi Thilal Al-Qur'an. Amman: Dar Majdalaw.

Bell, R. (1991). Translation and Translating: Theory and Practice. London: Longman. 
Catford, J. C. (1965). A Linguistic Theory of Translation. London: Oxford University press.

Clark, H. (1991). Responding to Indirect Speech Acts. In Davis, Steven (ed.), Pragmatics: A Reader (pp. 199-230). Oxford: Oxford University press.

Crystal, D. (2008). A Dictionary of Linguistics and Phonetics. Malden, M A: Blackwell.

Devine, A. M., \& Laurence, D. S. (2006). Latin Word Order. Oxford: Oxford University press. http://dx.doi.org/10.1093/acprof:oso/9780195181685.001.0001

Dickins, J., Hervey, S., \& Higgins, I. (2002). Thinking Arabic Translation: A Course in Translation Method: Arabic to English. London: Routledge.

Dik, H. (2007). Word Order in Greek Tragic Dialogue. Oxford: Oxford University press. http://dx.doi.org/10.1093/acprof:oso/9780199279296.001.0001

Eggins, S. (1994). An Introduction to Systemic Functional Linguistics. London: Pinter Publishers.

Enani, M. M. (2000a). Mostofa Mahmoud the Quran an Attempt at a Modern Reading. Cairo: Dar Al- Ma'aref.

Fatani, A. (2006). Translation and the Qur'an. In Leaman, Oliver, The Quran: An Encyclopedia. London: Routledge.

Ghali, M. M. (2005). Towards Understanding the Ever-Glorious Qur'an. Cairo: Dar An-Nashr Liljami.

Ghoneim, H. S. (2010). Linguistic Secrets and Verbal Implications of Qur'anic Verses. Cairo: Jazeerat Al -Ward.

Halliday, M. A. K., \& Ruqaiya, H. (1976). Cohesion in English. London: Longman.

Hartmann, R. R. K., \& James, G. (1998). Dictionary of Lexicography. London: Routledge. http://dx.doi.org/10.4324/9780203159040

Khan, M. M., \& M. Taqi-ud-Din Al-Hilali. (1996). Interpretation of the Meanings of the Noble Qur'an. Riyadh: Maktaba Dar-us-Salam.

Lambrecht, K. (1994). Information Structure and Sentence Shift. Cambridge: Cambridge University Press.

Lawrence, Bruce. (2006). The Qur'an: A Biography. London: Atlantic Books.

Lefevere, A. (1992). Translation, Rewriting and the Manipulation of Literary Fame. London \& Now York: Routledge.

Malmkjær, K. (2005). Linguistics and the Language of Translation. Edinburgh: Edinburgh University Press.

Nash, W. (1980). Designs in Prose. Essex: Longman.

Pellatt, V., \& Eric, T. Liu. (2010). Thinking Chinese Translation. London: Routledge.

Pickthall, M. M. (2001). The Meaning of the Glorious Qur'an. Kuala Lumpur: Islamic Book Trust.

Robbins, V. (1996). Exploring the Texture of Texts. Valley Forge, PA: Trinity Press International.

Simon, S. (1996). Gender in Translation. London: Routledge. http://dx.doi.org/10.4324/9780203202890

Smalley, W. (1991). Translation as Mission. Georgia: Mercer University press.

Trask, R. L. (1999). Key Concepts in Language and Linguistics. London: Routledge.

Ünal, A. (2006). The Qur'an: With Annotated Interpretation in Modern English. NJ: The Light, Inc.

Wright, W. (1967). A Grammar of the Arabic Language. Cambridge: CUP. 